\title{
Effects of environmental preconditioning, donor tissue and isolation conditions on tomato (Lycopersicon esculentum Mill.) protoplast yield
}

\section{ELŻBIETA KUŹNIAK, MARZENA WIELANEK, URSZULA MAŁOLEPSZA, HENRYK URBANEK}

\author{
Department of Plant Physiology and Biochemistry, University of Łódź, \\ Banacha 12/16, 90-237 Łódź, Poland
}

(Received: November 12, 1995)

\begin{abstract}
A b s tract
The effects of soil or in vitro grown plants, pretreatment conditions, donor tissue and isolation procedure on protoplast yield from cotyledons and leaves of tomato cv. 'Perkoz' and 'Zorza' were studied. The highest protoplast yield of $1.5 \times 10^{7} / \mathrm{g}$ FW was obtained from leaves of in vitro grown plants. Low light intensity during donor plants in vitro culture and dark pretreatment were essential for successful protoplast isolation while cold pretreatment was not. Tissue preplasmolysis prior to transfer to enzyme mixture increased 4 -fold the number of isolated protoplasts. Glycine and bovine serum albumin in the isolation medium did not significantly influence the protoplast yield.
\end{abstract}

\section{INTRODUCTION}

There is a steady progress towards effective use of protoplasts as a tool for modification of plant genome. The first prerequisite for the application of protoplasts to genetic transformation and somatic hybridization is an efficient, simple and repeatable method for protoplast isolation and culture. The successful protoplast isolation and subsequent plant regeneration depend on a genotype, growth conditions of the donor plants, environmental preconditioning of donor tissue, isolation procedure, medium composition and culture conditions. Although several reports on tomato protoplast isolation and plant regeneration have been published ( $\mathrm{L} \mathrm{e} \mathrm{f} \mathrm{r} \mathrm{a} \mathrm{n-}$ C o i s and $\mathrm{C}$ h u p e a u, 1993; P a t i 1 et al., 1994) relatively little information has been given explaining why the particular conditions to grow and handle donor plants 
were chosen. Contradictory results are sometimes obtained from similar plants or isolation conditions. For example, $\mathrm{S}$ h a h in (1985) was unable to isolate protoplasts from tomato plants grown in a greenhouse or in a growth chamber whereas $\mathrm{N} \mathrm{i} \mathrm{e} \mathrm{d} \mathrm{z}$ et al. (1985) developed a successful protocol for mesophyll protoplast isolation from tomato plants grown in a controlled environment chamber. According to $\mathrm{C} \mathrm{h}$ e $\mathrm{n}$ and A d a c h i (1994) dark and cold pretreatment was necessary for isolation of tomato cotyledon protoplasts and $\mathrm{H}$ o s s a in et al. (1995) developed an efficient method without any preconditioning of the donor tomato cotyledons. The procedure of potato protoplast isolation and regeneration described by $\mathrm{S} \mathrm{h}$ e p a r d (1977) later followed by other workers appeared ineffective ( $\mathrm{Ch}$ a n g and $\mathrm{L} \mathrm{o} \mathrm{e} \mathrm{s} \mathrm{c} \mathrm{h} \mathrm{e} \mathrm{r,} \mathrm{1991).}$

This paper describes the results of tests assessing the effects of plant origin, donor tissue, dark/cold pretreatment and isolation procedure on tomato protoplast yield.

\section{MATERIAL AND METHODS}

S o i 1 g row n p la n t s. Tomato (Lycopersicon esculentum Mill.) plants, cv. 'Perkoz' and 'Zorza', were grown in soil, in growth chamber at $23^{\circ} \mathrm{C}$ and $16 \mathrm{~h}$ photoperiod at 3000 lux. At the age of 2 weeks cotyledons, following preconditioning, were surface - sterilized (70\% ethanol, $3 \mathrm{~min}$.) followed by $3 \mathrm{~min}$. in $15 \%$ commercial bleach ("Bielnar"), washed 6 times with sterile distilled water and used for protoplast isolation.

In vitro grow n plant s. Seeds (cv. 'Perkoz' and 'Zorza') were sterilized as described for cotyledons (except for $30 \%$ commercial bleach used).

A. Seeds were germinated in glass vessels on TM-1 agar $(0.65 \%)$ medium $\left(\mathrm{S} \mathrm{h}\right.$ a h i n, 1985) without growth regulators at $23^{\circ} \mathrm{C}, 16 \mathrm{~h}$ photoperiod and at 1000 lux. Two-week-old cotyledons, following preconditioning, were used for protoplast isolation.

B. Sterile seeds were germinated on wet filter paper in petri-dishes. One week after germination the roots were cut off at the hypocotyl and the apical parts were transferred on TM-1 agar $(0.65 \%)$ medium. Seed germination and seedling growth was at $23^{\circ} \mathrm{C}, 16 \mathrm{~h}$ photoperiod with $600 \mathrm{lux}$ and 1000 or 3000 lux, respectively. Protoplasts were isolated from 2-week-old cotyledons or 3-week-old leaves after preconditioning.

$\mathrm{D}$ a r k / c o ld p ret re a t m e $\mathrm{n}$ t. Soil and in vitro grown plants were preconditioned immediately prior to protoplast isolation. The dark treatment included 0,24 and $48 \mathrm{~h}$ at $23^{\circ} \mathrm{C}$ and the cold treatment $-14 \mathrm{~h}$ at $10^{\circ} \mathrm{C}$, in the dark.

Protoplast is olation. Tomato protoplasts were isolated from cotyledon and leaf fragments according to the modified procedure of $\mathrm{S} \mathrm{h}$ a h in (1985). Cotyledons 
were sliced transversely into ca. $0.5 \mathrm{~cm}$ strips and placed into isolation medium. Leaves were prepared as follows:

a) the same as cotyledons,

b) leaf fragments were placed into preenzyme treatment solution (PET) (S h a h i n, 1985 ) for $14 \mathrm{~h}$, at $10^{\circ} \mathrm{C}$ and then to the isolation medium or

c) prior to transfer to PET solution leaf fragments were plasmolyzed for $1 \mathrm{~h}$ in $\mathrm{CPW}$ salt solution (P o w e r and $\mathrm{Ch}$ a p m a n, 1985) containing $9 \%$ mannitol.

The enzyme mixture consisted of $1.5 \%$ cellulase "Onozuka", $0.3 \%$ macerozyme, $0.3 \%$ driselase dissolved in CPW salt solution or in a solution described by $\mathrm{S} \mathrm{h}$ a h i n (1985). To determine the effect of glycine and bovine serum albumin during protoplast isolation $0.2 \mathrm{M}$ glycine in combination with $0.1 \mathrm{M}$ sucrose, instead of $0.3 \mathrm{M}$ sucrose or $0.1 \%$ bovine serum albumin, were added to the latter one. After $3 \mathrm{~h}$ of incubation at $27^{\circ} \mathrm{C}$ with gentle agitation in the dark the protoplast number was determined with a hemocytometer.

\section{RESULTS AND DISCUSSION}

In a preliminary experiment we used cotyledons of soil grown tomato plants cv. 'Perkoz' and 'Zorza' to isolate protoplasts. The attempts to isolate protoplasts from plants that were not preconditioned failed (Fig. 1). The $24 \mathrm{~h}$ dark pretreatment of plants prior to isolation resulted in a significant increase in protoplast yield (Fig. 1). Under the same pretreatment conditions cotyledon protoplast yield improved markedly when in vitro grown plants were used instead of those grown in soil (Fig. 2). It ranged from $3.5 \times 10^{5}$ protoplasts/g FW for 'Zorza' cultivar to $6.3 \times 10^{5}$ protoplasts/g FW for 'Perkoz' cultivar. Similarly, S h a h in (1985) was unable to isolate protoplasts from soil grown tomato plants and T a y lo r et al. (1988) observed an 8 -fold decrease in potato protoplast yield when donor plants were grown in vivo.

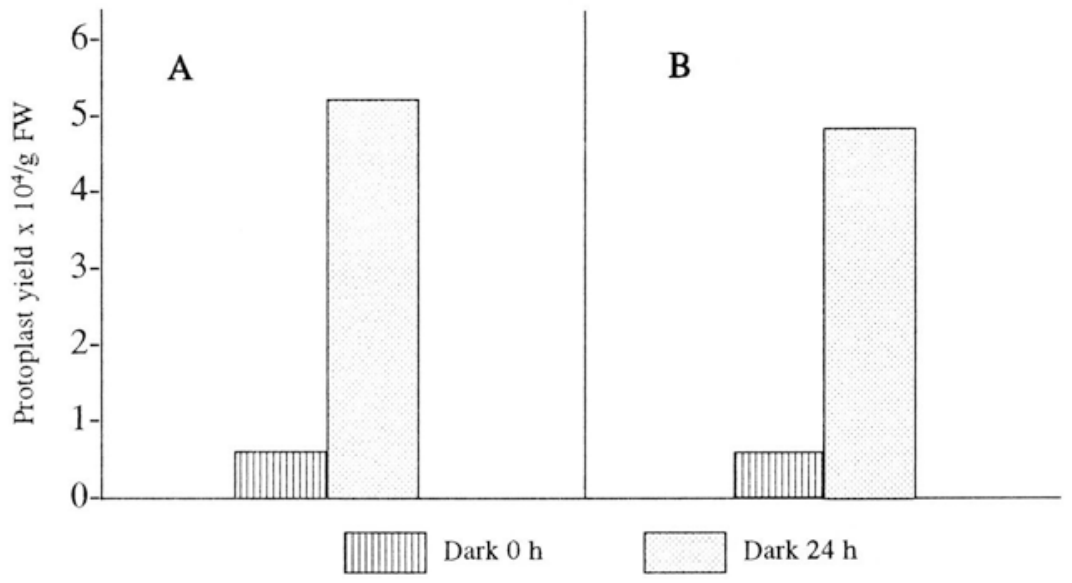

Fig. 1. The effect of dark pretreatment on cotyledon protoplast yield from soil grown tomato plants (A) cv. 'Perkoz' and (B) 'Zorza' 


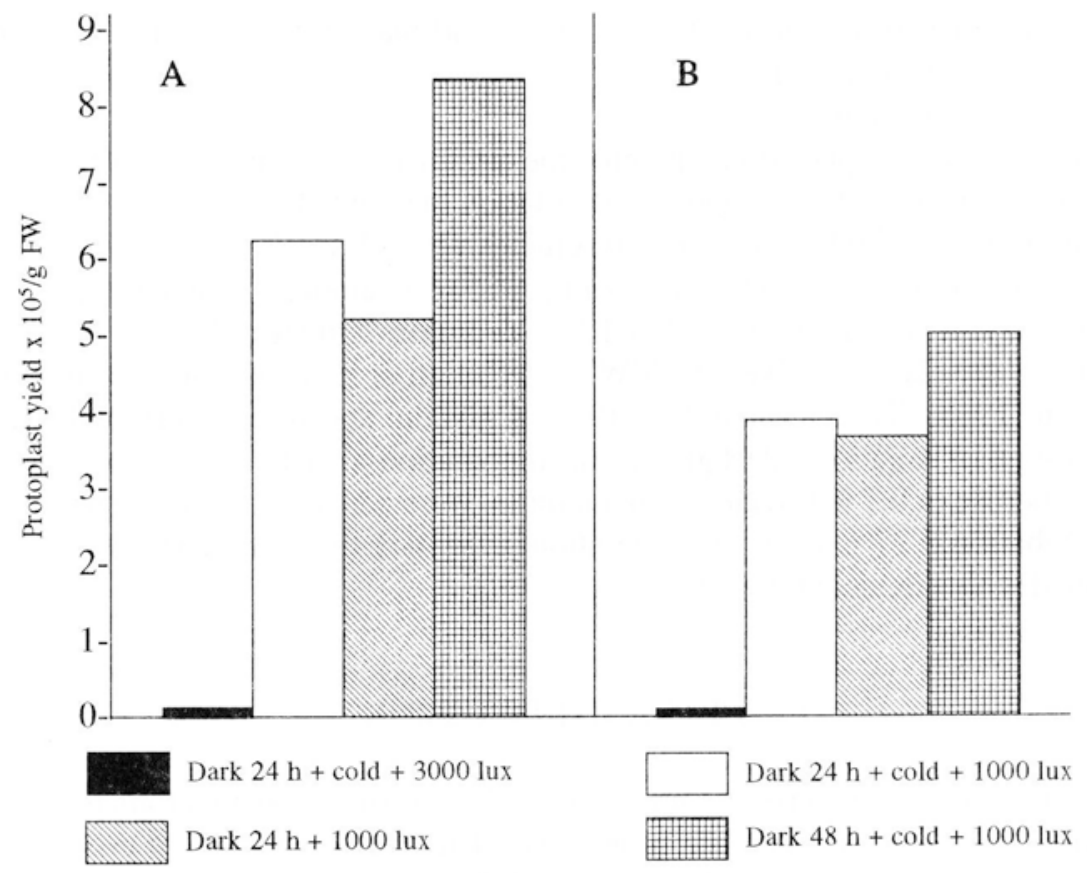

Fig. 2. The effect of preconditioning on cotyledon protoplast yield from in vitro grown tomato plants (A) cv. 'Perkoz'” and (B) 'Zorza'

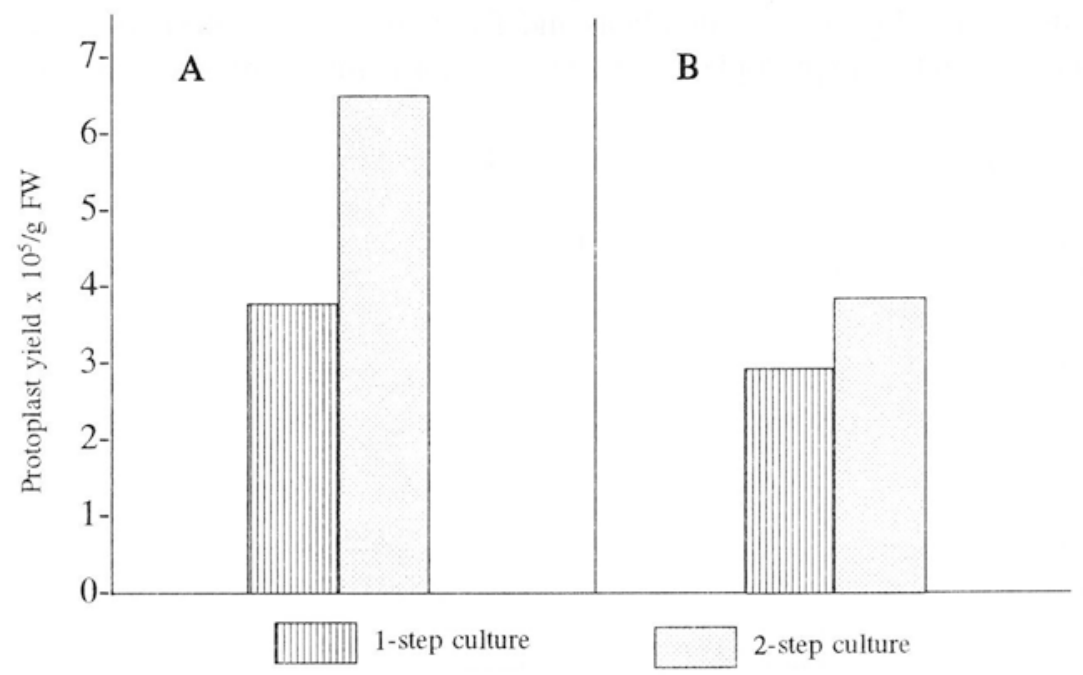

Fig. 3. The effect of donor plants in vitro culturing on cotyledon protoplast yield A - cv. 'Perkoz', B - cv. 'Zorza' 
Further we studied the effects of light intensity during donor plant growth, and the length of dark period and cold treatment prior to isolation on protoplast yield. The low light intensity during in vitro culture was crucial for protoplast isolation from cotyledons (Fig. 2). The use of plants continuously growing with high light intensity resulted in an over $90 \%$ decrease in the protoplast yield (Fig. 2). When the dark period was extended from 24 to $48 \mathrm{~h}$ we observed $30 \%$ increase in the number of isolated protoplasts. Cold preconditioning $\left(10^{\circ} \mathrm{C}\right.$ for $\left.14 \mathrm{~h}\right)$ did not significantly increase the protoplast yield. Our results are consistent with the observations of M o n t a g n o et al. (1991) and W i j b ran d i et al. (1990) that cold pretreatment is not essential for tomato protoplast isolation. The dark/cold pretreatment was reported to be necessary to obtain high yields of viable protoplasts ( $\mathrm{T}$ a $\mathrm{n}$ et al., 1987; $\mathrm{N} \mathrm{i} \mathrm{e} \mathrm{d} \mathrm{z} \mathrm{and} \mathrm{S} \mathrm{i} \mathrm{n} \mathrm{k,} \mathrm{1988)} \mathrm{yet} \mathrm{its} \mathrm{beneficial} \mathrm{effect} \mathrm{was} \mathrm{not} \mathrm{fully} \mathrm{explained.} \mathrm{It}$ is suggested that it reduces the physiological stress during isolation $(\mathrm{C} \mathrm{h}$ e $\mathrm{n}$ and A d a c h i, 1994).

We observed that under all tested environmental conditions the tendency of changes was similar regardless of plant cultivar. However, under the given conditions higher yield was always obtained from plants cv. 'Perkoz' (Fig. 2). We observed that in vitro culturing of the donor plants also affected the response. When cotyledons with uncutted roots (from 1-step in vitro culture) were used the yield of protoplasts decreased by $69 \%$ and $38 \%$ for 'Perkoz' and 'Zorza', respectively (Fig. 3). The obtained results demonstrated that the preconditioning giving the highest cotyledon protoplast yield was: 2-step in vitro culture, low light intensity for plant growth, $48 \mathrm{~h}$ dark and $14 \mathrm{~h}$ cold pretreatment. Initially we attempted to optimize cotyledon protoplast isolation method because it has been reported that cotyledons, when compared with leaves, offer an easily reproducible and physiologically more stable tissue ( $\mathrm{C} \mathrm{h}$ e $\mathrm{n}$ and $\mathrm{A} \mathrm{d} \mathrm{a} \mathrm{c} \mathrm{h} \mathrm{i,} \mathrm{1994).} \mathrm{However,} \mathrm{the} \mathrm{protoplast} \mathrm{yield} \mathrm{of}$ $8.5 \times 10^{5} / \mathrm{g} \mathrm{FW}$ obtained under our conditions was unsatisfactory.

Further we studied the effect of the leaf tissue on the protoplast yield. The use of tomato leaves, preconditioned according to the above optimum procedure for cotyledons, increased the protoplast yield up to $1.4 \times 10^{6} / \mathrm{g} \mathrm{FW}$ as compared with $8.5 \times 10^{5} / \mathrm{g}$ FW for cotyledons (Fig. 4). Furthermore, the $12 \mathrm{~h}$ preincubation of the sliced leaflets in PET solution prior to transfer to the enzyme mixture and especially $1 \mathrm{~h}$ preplasmolysis before PET treatment had a marked effect on protoplast release from leaves. Incubating leaf strips in a plasmolysing solution increased 4-fold the number of isolated protoplasts (Fig. 5). The obtained yield, $1.5 \times 10^{7}$ protoplasts/g FW was similar to those of tomato mesophyll protoplasts e.g. the results of $\mathrm{M} \mathrm{o} \mathrm{n-}$ $\mathrm{t}$ a $\mathrm{g} \mathrm{n}$ o et al. (1991) ranged from $2.0 \times 10^{6}$ to $1.7 \times 10^{7}$ protoplasts $/ \mathrm{g} F \mathrm{~F}$ and the method of $\mathrm{N} \mathrm{i} \mathrm{e} \mathrm{d} \mathrm{z} \mathrm{et} \mathrm{al.} \mathrm{(1985)} \mathrm{yielded} 1.0 \times 10^{6}$ protoplasts/g FW.

$\mathrm{Ch}$ a $\mathrm{ng}$ and $\mathrm{L} \mathrm{o}$ e s c h e r (1991) reported that regardless of pretreatment effects a combination of glycine and sucrose in the isolation medium increased potato protoplast yield at least 2 -fold which might suggest that glycine acts as a membrane stabilizing agent. T a y 1 or et al. (1989) obtained a significant increase in potato protoplast yield using bovine serum albumin during isolation. They 
suggested that bovine serum albumin may act as a potential substrate for protease contaminating commercial enzyme preparations and therefore the protoplast survival during tissue digestion was enhanced. Our results did not demonstrate that bovine serum albumin or the combination of $0.2 \mathrm{M}$ glycine and $0.1 \mathrm{M}$ sucrose influence mesophyll protoplast isolation (Fig.6).

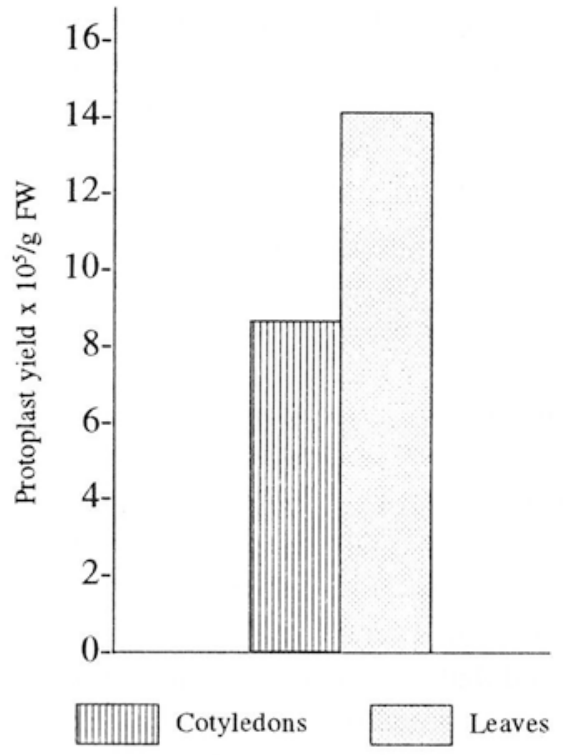

Fig. 4. The effect of donor tissue on protoplast yield from tomato plants cv. 'Perkoz' grown in vitro

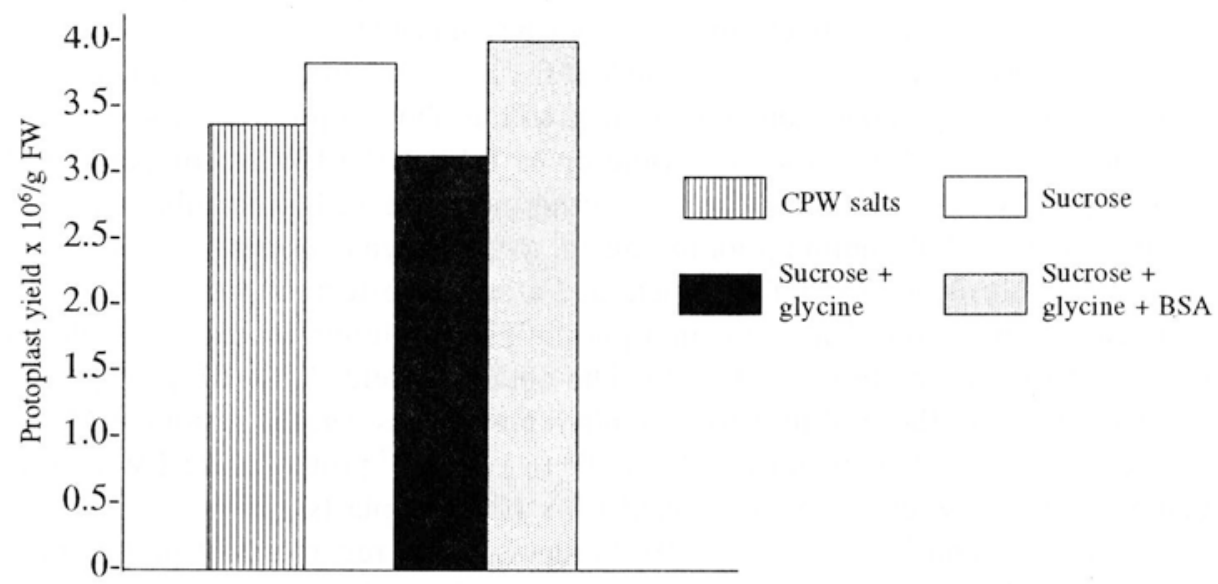

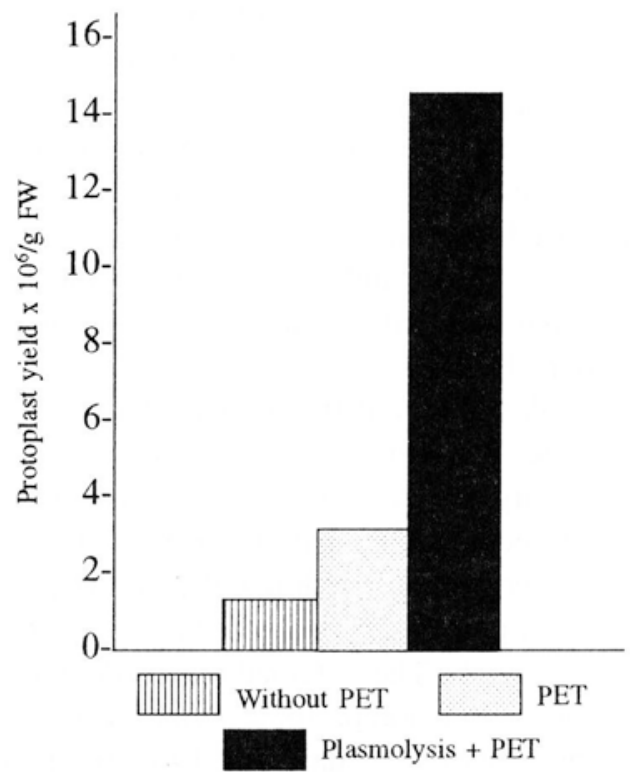

Fig. 5. The effect of leaf tissue treatment prior to isolation on protoplast yield from plants cv. 'Perkoz' grown in vitro

Fig. 6. The effect of non-enzymatic isolation medium components on mesophyll protoplast yield from plants cv. 'Perkoz' grown in vitro. CPW salts or a solution according to $\mathrm{S}$ h a h i n (1985) with $0.3 \mathrm{M}$ sucrose, and a combination of $0.2 \mathrm{M}$ glycine and $0.1 \mathrm{M}$ sucrose with or without $0.1 \%$ bovine serum albumin (BSA) were used 
In conclusion our results indicated that low light intensity during donor plant culture and dark pretreatment are necessary for high tomato protoplast yield. Leaves of in vitro grown plants used for protoplast isolation instead of cotyledons resulted in higher yield. The developed method provided consistently high yields of mesophyll protoplasts suitable for regeneration, fusion experiments and electroporation.

Acknowledgement: This work has been supported by University of Łódź, Grant No 505/726.

\title{
REFERENCES
}

$\mathrm{C}$ h a n g M., L o e s c h e r W. H., 1991. Effects of preconditioning and isolation conditions on potato (Solanum tuberosum L. cv. Russet Burbank) protoplast yield for shoot regeneration and electroporation. Plant Sci. 73: 103-109.

C h e n L. Z., A d a c h i T., 1994. Plant regeneration via somatic embryogenesis from cotyledon protoplasts of tomato (Lycopersicon esculentum Mill.). Japan. J. Breed. 44: 257-262.

Hos s a in M., I m a n is h i S., E g a s h i r a H., 1995. An improvement of tomato protoplast culture for rapid plant regeneration. Plant Cell Tiss. Org. Cult. 42: 141-146.

Le f r a n c o is C., C h u p e a u Y., 1993. Standard conditions for plant regeneration from leaf protoplasts of several Lycopersicon species. J. Plant Physiol. 141: 629-632.

M o n t a g n o T. J., J o u r d a n P. S., B e r r y S. Z., 1991. Plant regeneration from leaf protoplasts of Lycopersicon hirsutum f. hirsutum. Plant Cell Rep. 9: 68()-683.

$\mathrm{N}$ i e d z R. P., R u t t e r S. M., H a n d I e y L. W., S i n k K. C., 1985. Plant regeneration from leaf protoplasts of six tomato cultivars. Plant Sci. 39: 199-204.

$\mathrm{N}$ i e d z R. P., S i n k K. C., 1988. Multifactor analysis of environmental preconditioning of tomato seedlings on protoplast culture and development. J. Plant Physiol. 133: 385-391.

P a t i I R. S., D a v e y M. R., P o w e r J. B., 1994. Highly efficient plant regeneration from mesophyll protoplasts of Indian field cultivars of tomato (Lycopersicon esculentum). Plant Cell Tiss. Org. Cult. 36: $255-258$.

P ow e r J. B., C h a p m a n J. V., 1985. Isolation, culture and genetic manipulation of plant protoplasts. |In:| R. A. Dixon (ed.) Plant cell culture: a practical approach. IRL Press, Oxford, Washington, pp. 37-66.

S h a h i n E. A., 1985. Totipotency of tomato protoplasts. Theor. Appl. Genet. 69: 235-240.

S h e p a rd J. F., T ot te n R. E., 1977. Mesophyll cell protoplasts of potato. Plant Physiol. 60: 313-316.

T a n M. C., R i e tve I d E. M., V a n M arrew i j k G. A. M., Ko ol A. J., 1987. Regeneration of leaf mesophyll protoplasts of tomato cultivars ( $L$. esculentum): factors important for efficient protoplast culture and plant regeneration. Plant Cell Rep. 6: 172-175.

T a y I o r R. J., R u b y C. L., S e c o r G. A., 1989. Effects of enzyme dialysis, cellulase concentration. bovine serum albumin and origin of source leaflet tissue on yield and plating efficiency of potato mesophyll protoplasts. Biochem. Physiol. Pflanzen. 185: 227-232.

WijbrandiJ., Van Capelle W., HanhardC. J., Van Loenen Martinet-Schuringa E. P., K o o r n n e e f M., 1990. Selection and characterization of somatic hybrids between Lycopersicon esculentum and Lycopersicon peruvianum. Plant Sci. 70: 197-208.

\section{Wpływ prekondycjonowania, rodzaju tkanki i warunków izolacji na} otrzymywanie protoplastów pomidora (Lycopersicon esculentum Mill.)

\author{
Streszczenie
}

Badano wydajność izolowania protoplastów z pomidora odm. 'Perkoz' i 'Zorza' w zależności od warunków hodowli roślin, rodzaju tkanki, prekondycjonowania i procedury izolacyjnej. Najwyższą wydajność 
$1,5 \times 10^{7}$ protoplastów/g s.m. otrzymano z liści roślin hodowanych in vitro. Stwierdzono, że niska intensywność oświetlenia w czasie hodowli in vitro i przechowywanie roślin w ciemności przed izolacją stanowią warunek konieczny dla uzyskania dużej wydajności. Przechłodzenie materiału nie wpływało istotnie na ilość otrzymywanych protoplastów. Plazmoliza tkanki przed przeniesieniem do mieszaniny enzymatycznej zwiększała czterokrotnie wydajność izolacji. Obecność glicyny i albuminy z surowicy wołowej w podłożu izolacyjnym nie miała istotnego wpływu na ilość otrzymywanych protoplastów. 